\title{
Ultrasonography of Udder Parenchymal Tissue of Murrah and Swamp Buffalo Calves
}

\author{
Ulum $\mathrm{MF}^{1}$, Raudlowi $\mathrm{H}^{2}$, Krisnan $\mathrm{R}^{3}$ \\ ${ }^{I}$ Departement of Reproduction and Pathology Clinic, Faculty of Veterinary, Bogor Agricultural University \\ ${ }^{2}$ Education Program for Doctor of Veterinary Medicine, Faculty of Veterinary, Bogor Agricultural University \\ ${ }^{3}$ Indonesian Research Institute for Animal Production, PO Box 221, Ciawi, Bogor \\ E-mail: ulum@ipb.ac.id
}

(received 10-04-2017; revised 15-06-2017; accepted 22-06-2017)

\begin{abstract}
ABSTRAK
Ulum MF, Raudlowi H, Krisnan R. 2017. Pencitraan ultrasonografi jaringan parenkim ambing anak kerbau Murrah dan Rawa. JITV 22(2): 57-62. DOI: http://dx.doi.org/10.14334/jitv.v22i2.1629

Pemeriksaan organ ambing melalui parameter berupa parenkim ambing (PAR) dan bantalan lemak ambing (MFP) dapat dilakukan untuk memantau status kesehatan dan perkembangan kelenjar ambing. Penelitian ini dilakukan untuk memantau PAR dan MFP pada ambing ternak kerbau jenis Murrah dan Rawa menggunakan ultrasonografi mode-brightness secara transkutan. Sebanyak 8 ekor kerbau berjenis Murrah $(n=4)$ dan Rawa $(n=4)$ berumur 6 bulan yang dipelihara di Balai Penelitian Ternak (Balitnak) Ciawi Bogor digunakan dalam penelitian ini. Pencitraan ultrasonografi dilakukan pada pangkal puting ambing dan dilakukan pada ke empat kuartir ambing yaitu kiri depan, kiri belakang, kanan depan, dan kanan belakang. Citra ultrasonografi di evaluasi dan di nilai pada skor, ekogenitas dan luasan PAR dalam MFP. Hasil pencitraan menunjukkan bahwa sonogram PAR tampak anekoik hingga hipoekoik, sedangkan MFP tampak hipoekoik hingga hiperekoik. Meskipun terdapat variasi diantara kuartir ambing, nilai skor dan ekogenitas serta luas PAR dalam MFP pada kerbau Murrah memiliki nilai yang lebih tinggi dibandingkan dengan kerbau Rawa $(\mathrm{P}>0.05)$.
\end{abstract}

Kata Kunci: Ambing, Anak Kerbau, Parenkim Ambing (PAR), Bantalan Lemak Ambing (MFP), Ultrasonografi

\section{ABSTRACT}

Ulum MF, Raudlowi H, Krisnan R. 2017. Ultrasonography of udder parenchymal tissue of Murrah and Swamp buffalo calves. JITV 22(2): 57-62. DOI: http://dx.doi.org/10.14334/jitv.v22i2.1629

The examination of udder through a parameter such as parenchymal tissue (PAR) and mammary fat pads (MFP) can be used to evaluate health status and the development of mammary gland. This research was conducted to evaluate the PAR and MFP of Murrah $(n=4)$ and Swamp $(n=4)$ buffalo heifer calve udder using brightness-mode ultrasonography transcutaneously. Eight buffalo consisted of Murrah $(n=4)$ and Swamp $(n=4)$ buffalo aged of six months old reared at Indonesian Research Institute for Animal Production, Ciawi, Bogor were used this study. Ultrasonography imaging was performed on the udder nipple for the four quarters: left front, left back, right front, and right back. The ultrasonography image was evaluated and then assessed for score, echogenicity and PAR area on MFP. The results showed that sonogram PAR was aniconic to hypoechoic, while the MFP was hypoechoic to hyperechoic. Even though there was a variation in the four quarters of udder, Murrah buffalo calve had the highest $(\mathrm{P}>0.05)$ value of score, echogenicity, and PAR area compared to the Swamp buffalo.

Key Words: Udder, Buffalo Calve, Udder Parenchymal (PAR), Mammary Fat Pads (MFP), Ultrasonography

\section{INTRODUCTION}

Milk production in Indonesia needs to be increased to fulfill milk protein requirement. Domestic milk production only meets $30 \%$ ( 0.9 million ton) of total requirement, therefore an importation is conducted to overcome the shortcomings (DGLAH 2017). Generally, milk is produced by milk producer livestock such as dairy cattle, buffalo, dairy goat, dairy sheep, horse and camel. The main milk producer livestock in Indonesia is crossed Friesian Holstein (FH) cattle. Other livestock animal that can be used as milk producer is buffalo. The current milk production of buffalo is $0.5-2.25$ $\mathrm{kg} /$ head/day (Wirdahayati 2007), while the milk production of $\mathrm{FH}$ cattle reaches $14.08 \mathrm{~kg} / \mathrm{head} / \mathrm{day}$ (Awan et al. 2016).

Indonesia has buffalo rearing center in many areas with the population of 1.3 million heads and the growth rate by $3.14 \%$ per year (DGLAH 2014). Almost $95 \%$ of the population is the swamp buffalo with a varied diversity on color, size, and behavior; and the $5 \%$ is the river buffalo (Dudi 2007). Commonly, the swamp buffalo is dairy buffalo, but its development is limited leads to the low production. The Province of West Sumatera is one of the areas that produces milked and processed buffalo milk for a long time (Ibrahim 2008). 
However, its rearing in conventional technique. Therefore, a study examination of buffalo as milk producer needs to be conducted.

Selection of the superior cow and bull has a crucial role in improving the productivity of dairy buffalo. Suhardono (2004) suggested that the best selection of cow and bull respectively was $50 \%$ and $20 \%$ of the offspring to create seedlings with good milk production. Milk is produced by mammary gland consisting of udder parenchymal (PAR) and mammary fat pads (MFP). Udder examination for the PAR and MFP can be done to evaluate the health and development of udder. The PAR and MFP parameters can be examined using ultrasonography imaging since early stage at the 2 months of age (Esselburn et al. 2015). The early evaluation of udder quality needs to be conducted to evaluate the potential quality of mammary gland. However, there is no report of ultrasonography evaluation on the buffalo mammary in Indonesia. This study was conducted to evaluate the PAR and MFP of Murrah and Swamp heifer calves mammary using brightness ultrasonography method.

\section{MATERIALS AND METHODS}

\section{Experimental animals}

As much as eight of six months Murah $(n=4)$ and Swamp $(n=4)$ heifer calves buffalo reared at Indonesian Research Institute for Animal Production, Ciawi, Bogor were used in this research.

\section{Ultrasonography imaging}

Ultrasonography imaging of mammary gland transcutant was performed using ultrasonography portable Chison Q8 ${ }^{\circledR}$ (PT Mega Utama Medica, Indonesia). The calves were handled manually in the cage without sedation (Figure 1). Ultrasonography gel was applied evenly on the udder surface. The transducer was firmly affixed to the udder to result in the good image. Ultrasonography imaging was performed started from the back of the nipple base on the four quarters. Imaging method followed the procedure of Nishimura et al. (2011) and Albino et al. (2015) for dairy cattle. The sonogram was caught from the transversal point of view using transducer multi linear frequency of 7.5-15 MHz. The imaging angle was conducted in the ventrodorsal direction of the body so that the skin, PAR and MFP tissue were well visible and could be clearly observed in sonograms. The sonogram was saved in the form of BMP for further analysis using Image ${ }^{\circledR}$ software (NIH, USA).

The sonogram obtained was assessed descriptively for PAR and MFP. Further analysis of the score, echogenicity and area of each PAR and MFP used Image ${ }^{\circledR}$ software (NIH, USA). One way ANOVA and Duncan post hoc test with $95 \%$ of the confidential interval used SPSS v. 16.0 SPSS Inc., USA) software to determine the difference of the parameter assessed. The value of $\mathrm{P}<0.05$ showed a significant difference between the group.

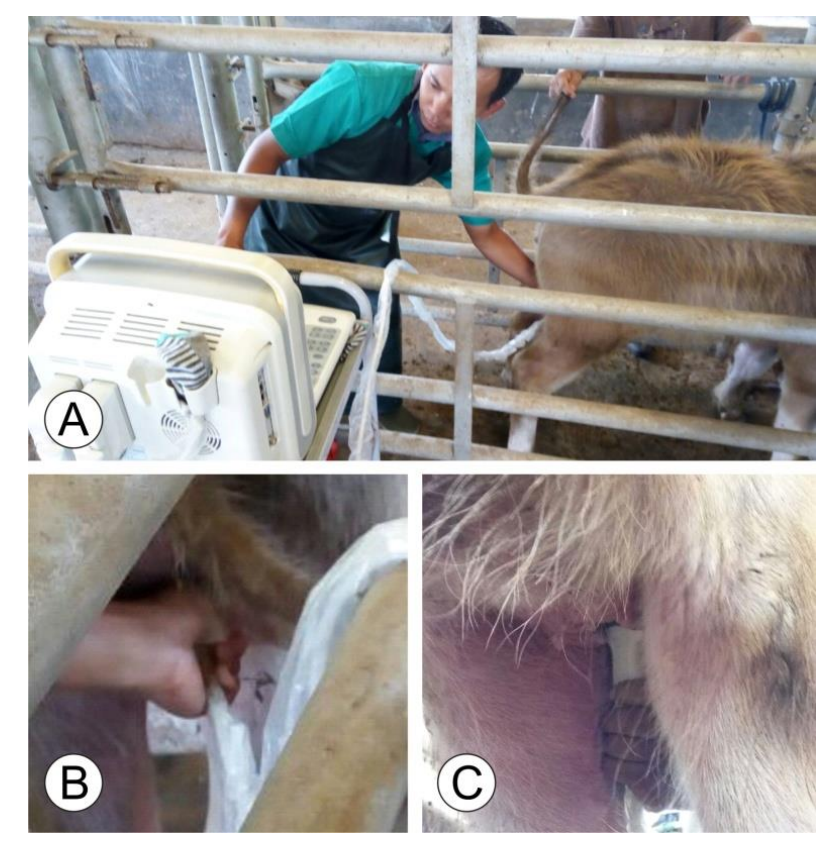

Figure 1. Ultrasonography imaging of parenchymal tissue (PAR) and mammary fat pads (MFP) of buffalo calve udder. (A) Side view, (B) back view, (C) front view. 


\section{RESULTS AND DISCUSSION}

The sonogram showed different udder from each individual or each quarter (Figure 2). The structure of tissue showed on the sonogram from the outside to the inside was skin, subcutaneous, parenchyma, fat pads, and peritoneal cavities. Echogenicity of the skin was hypoechoic to hyperechoic. Then the subcutaneous tissue under the skin has the similar echogenicity: hypoechoic to hyperechoic. The barrier between subcutaneous and muscle was fascia that looks like hyperechoic line. Udder parenchyma was in the subcutaneous area surrounded by the mammary fat pads. Udder parenchyma was anechoic to hypoechoic, while the mammary fat pad was hypoechoic to hyperechoic. The deeper image of sonogram was anechoic as a peritoneum space.

Figure 3 shows udder parenchymal (PAR) and mammary fat pad (MFP) scores of each quarter of buffalo calve udder. The PAR and MFP scores on the four quarter of those two buffalo calve udders had a various score. The Murrah buffalo calve had the highest average PAR scores than the Swamp buffalo, while the highest MFP scores was on the Murrah buffalo calve.
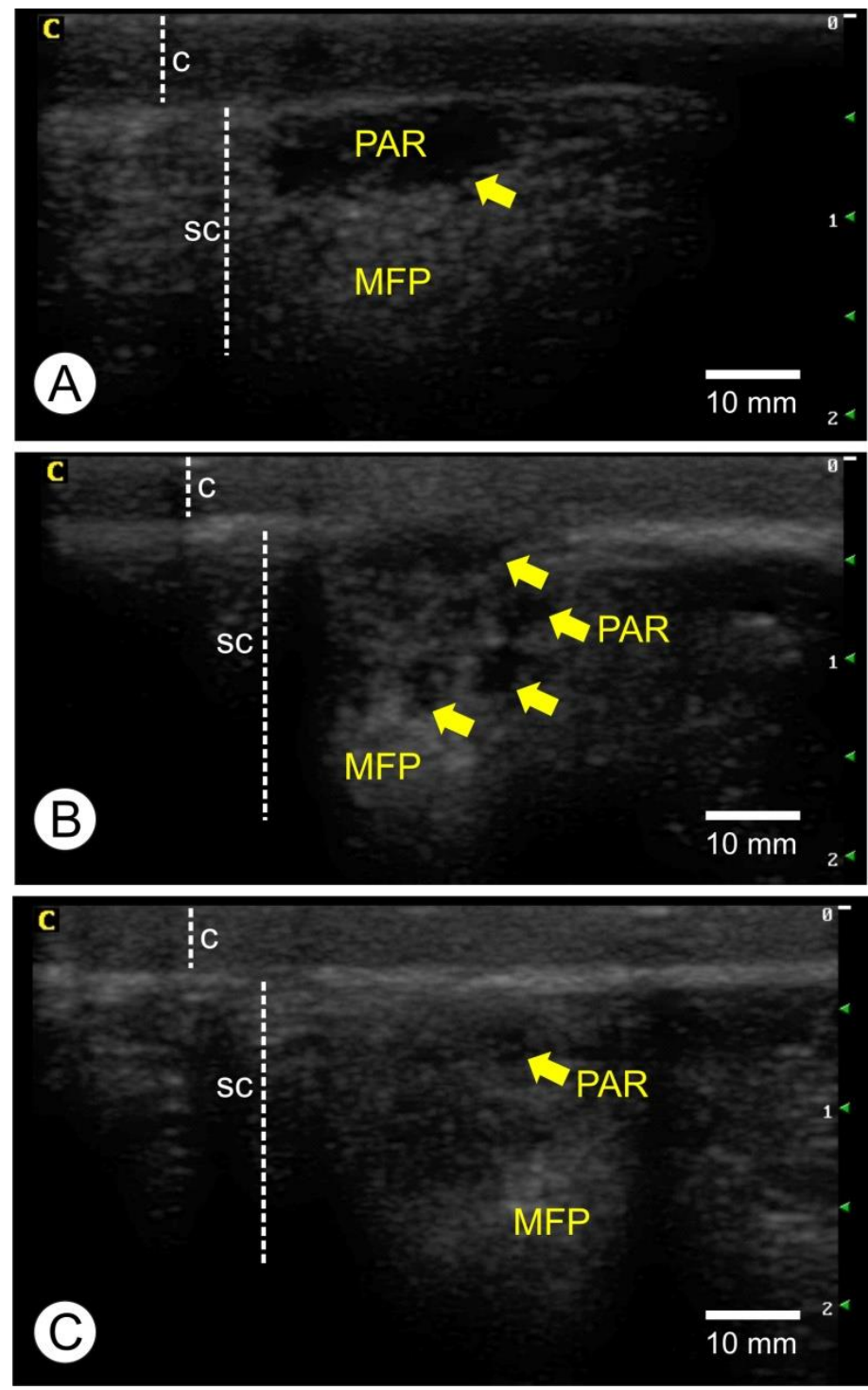

Figure 2. Sonogram of buffalo calves udder with the parenchyma tissue (PAR) showed by the arrow and mammary fat pads (MFP) under skin (C) in the subcutaneous area (sc).

(A) Murrah calves udder of the front left quarter with wide PAR

(B) Rawa calve udder of right back quarter with medium PAR size

(C) Swamp calve udder of right back quarter with small PAR size.

Note: the arrow $(\rightarrow)$ shows the PAR in the MFP.. 


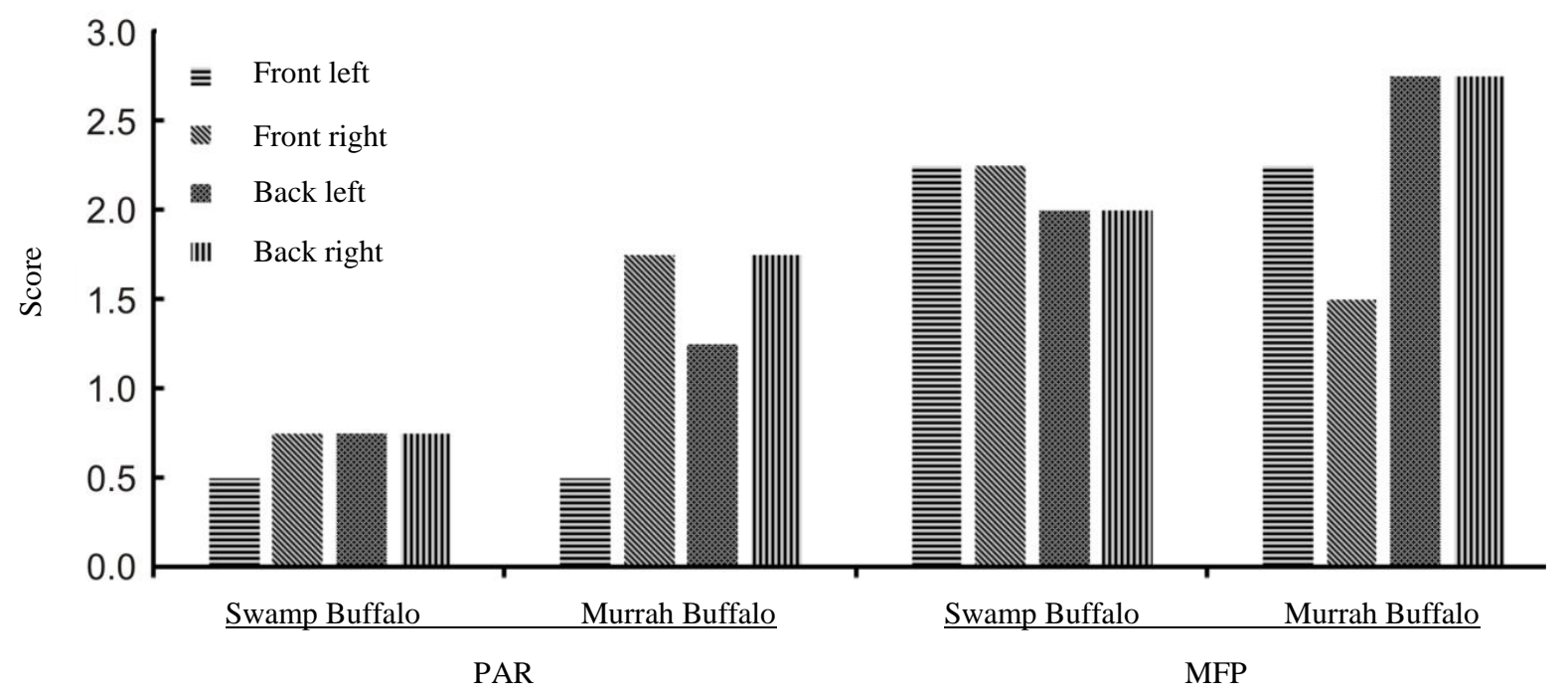

Figure 3. The average score of udder parenchymal (PAR) and mammary fat pads (MFP) of each quarter of buffalo calve udder. Score: $<1=$ very small PAR size/thin MFP, $1-<2=$ small PAR/medium MFP, $\geq 2=$ medium PAR/thick MFP.

Table 1. Sonogram echogenicity of parenchyma (PAR) and mammary fat pads (MFP) of each quarter of buffalo calve udder

\begin{tabular}{lcccc}
\hline \multirow{2}{*}{ Buffalo } & \multicolumn{4}{c}{ Quarter of Udder } \\
\cline { 2 - 4 } & Front left & Front right & Back left & Back right \\
\hline \multirow{2}{*}{ Swamp } & \multicolumn{4}{c}{ Parenchymal (PAR) (a.u.) } \\
Murrah & $18.44 \pm 3.48^{\mathrm{a}}$ & $21.96 \pm 2.30^{\mathrm{a}}$ & $24.34 \pm 6.14^{\mathrm{a}}$ & $24.70 \pm 4.11^{\mathrm{a}}$ \\
& $22.89 \pm 10.60^{\mathrm{a}}$ & $29.64 \pm 9.23^{\mathrm{a}}$ & $33.00 \pm 12.75^{\mathrm{a}}$ & $20.09 \pm 5.12^{\mathrm{a}}$ \\
Swamp & & Mammary Fat Pads (MFP) (a.u.) & $40.87 \pm 6.25^{\mathrm{a}}$ \\
Murrah & $44.39 \pm 10.63^{\mathrm{a}}$ & $47.21 \pm 2.46^{\mathrm{a}}$ & $49.84 \pm 4.75^{\mathrm{a}}$ & $47.73 \pm 6.93^{\mathrm{a}}$ \\
\hline
\end{tabular}

Data are presented in the form of average and standard deviation $(\mathrm{x} \pm \mathrm{SD})$. The different superscript shows a significant difference $(\mathrm{P}<0.05)$.

Table 1 shows the echogenicity of the sonogram of the PAR and MFP of each quarter of udder. The PAR echogenicity was lower than the MFP both on the Swamp and Murrah buffalo claves. The Murrah buffalo calve had higher PAR average and MFP echogenicity than the Swamp buffalo clave. The PAR and MFP of each quarter of udder had various echogenicity even though the statistical test showed that the PAR and MFP echogenicity of each quarter did not significantly different $(\mathrm{P}>0.05)$.

Analysis of the PAR and MFP area of each quarter was presented in Table 2. The PAR and MFP area were similar in each quarter and two breeds. The Murrah buffalo calve had wider PAR area than the Swamp buffalo calve on each quarter. The back quarter of udder had wider average PAR than the front quarter. Whereas, the right and left quarter had similar PAR area. Statistical test showed that the PAR area of each quarter of the two breeds did not significantly different $(\mathrm{P}>0.05)$.

This research successfully showed the difference of sonogram of each quarter (Figure 1). The tissue structure of superficial ultrasonography imaging was: skin, subcutaneous, fat pads, parenchyma and peritoneal space. The skin consists of 2 layers: epidermis that is hyperechoic and dermis that is hypoechoic (Wortsman \& Navarrete 2017). The echogenicity of epidermis depends on the thickness of the stratum corneum, while the dermis echogenicity depends on the number of collagen fibers and the intracellular matrix (Szymanska et al. 2000). The subcutaneous layer appeared on the sonogram under the skin (Figure 2). The echogenicity of subcutaneous layer of udder was hyperechoic, because it consists of soft tissue and lots of fat tissue (Szymanska et al. 2000; Nishimura et al. 2011). 
Ulum et al. Ultrasonography of udder parenchymal tissue of Murrah and Swamp buffalo calves

Table 2. Parenchymal tissue (PAR) area and mammary fat pads (MFP) of each quarter of buffalo calve udder

\begin{tabular}{|c|c|c|c|c|}
\hline \multirow{2}{*}{ Buffalo } & \multicolumn{4}{|c|}{ Quarter of Udder } \\
\hline & Front left & Front right & Back left & Back right \\
\hline & \multicolumn{4}{|c|}{ Parenchymal (PAR) $\left(\mathrm{cm}^{2}\right)$} \\
\hline Swamp & $0.267 \pm 0.079^{\mathrm{a}}$ & $0.253 \pm 0.146^{\mathrm{a}}$ & $0.201 \pm 0.040^{\mathrm{a}}$ & $0.256 \pm 0.130^{\mathrm{a}}$ \\
\hline Murrah & $0.273 \pm 0.150^{\mathrm{a}}$ & $0.297 \pm 0.225^{\mathrm{a}}$ & $0.419 \pm 0.042^{\mathrm{a}}$ & $0.416 \pm 0.234^{\mathrm{a}}$ \\
\hline
\end{tabular}

Description: Data were presented in the form of average and standard deviation $(x \pm S D)$.

The different superscript shows a significant difference $(\mathrm{P}<0.05)$.

The mammary gland consists of parenchymal tissue as the main milk producer tissue and fat pad that supports the position of parenchymal tissue (Esselburn et al. 2015). Nishimura et al. (2011) reported that the mammary gland of two months calves was clearly oval and hypoechoic, while the PAR of five months calves was irregular in shapes and sometimes just looked like an anechoic canal and the increasing of echogenicity. This study shows that the development of mammary gland can be evaluated through the increase of the PAR echogenicity (Table 1). The older the animal, the PAR shape will expand, thicken and create branches (Akers et al. 2000). The increase of MFP echogenicity shows the thickness of fat tissue of the udder (Esselburn 2012). The thickness of MFP shows the improvement of the udder quality (Meyer et al. 2006).

The ultrasonography imaging score showed that the PAR and MFP of Murrah buffalo calve was higher than that of Swamp buffalo calve (Figure 3). Further analysis of the PAR area showed that the Murrah buffalo calves had wider area than the Swamp buffalo (Table 2). The higher score and wider area can be concluded that the quality and production of Murrah buffalo milk will be higher than the Swamp buffalo. Murrah buffalo is a dairy buffalo and is one of the river buffalos, while the Swamp buffalo is reared as working animal and meat producer, even in several areas it is also milked (Sutama 2008). The wide PAR area of buffalo calve can be predicted that it will result in development of huge cisterna udder. The huge cisterna udder will result in high milk production (Ayadi et al. 2002). The PAR area of the back udder was wider than the front. This result is similar to the research conducted by Esselburn et al. (2015) who reported that the ratio of front and back quarter area was 47:53.

\section{CONCLUSION}

An evaluation of parenchymal tissue (PAR) and mammary fat pads (MFP) of buffalo calve is easy to be performed using ultrasonography. The difference of parameter on the score, echogenicity and PAR area in MFP may be used to predict the potential of the quality of udder. Ultrasonography imaging showed a better udder quality of Murrah calve compared to the Swamp calve.

\section{ACKNOWLEDGEMENT}

We appreciate the PT Mega Utama Medica that facilitated the ultrasonography tools for this study.

\section{REFERENCES}

Akers RM, McFadden TB, Purup S, Vestergaard M, Sejrsen K, Capuco AV. 2000. Local IGF-I axis in peripubertal ruminant mammary development. J Mammary Gland Biol Neoplasia. 5:43-51.

Albino RL, Marcondes M I, Akers RM, Detmann E, Carvalho BC, Silva TE. 2015. Mammary gland development of dairy heifers fed diets containing increasing levels of metabolisable protein: metabolisable energy. J Dairy Res. 82:113-120.

Awan JS, Atabany A, Purwanto BP. 2016. Pengaruh umur beranak pertama terhadap performa produksi susu sapi Friesian Holstein di BBPTU-HPT Baturraden. Jurnal Ilmu Produksi dan Teknologi Hasil Peternakan. 4:306311.

Ayadi M, Caja G, Such X, Knight CH. 2003. Use of ultrasonography to estimate cistern size and milk storage at different milking intervals in the udder of dairy cows. J Dairy Research. 70:1-7.

[DGLAH] Directorate General of Livestock and Animal Health. 2017. Statistik Peternakan dan Kesehatan Hewan. Jakarta (ID): Directorate General of Livestock and Animal Health, Ministry of Agriculture. Republic of Indonesia. p. 113.

[DGLAH] Directorate General of Livestock and Animal Health. 2014. Laporan Tahunan Direktorat Jenderal Peternakan dan Kesehatan Hewan tahun 2014. Jakarta (Indones): Directorate General of Livestock and Animal Health, Ministry of Agriculture, Republic of Indonesia. p. 9.

Dudi. 2007. Peningkatan produktivitas kerbau lumpur (Swamp Buffalo) di Indonesia melalui kegiatan pemuliaan ternak berkelanjutan (Review). Prosiding Seminar Nasional 
Peternakan-Perikanan 2007. Malang (Indones): Universitas Muhammadiyah Malang.

Esselburn KM, Hill TM, Bateman HG, Fluharty FL, Moeller SJ, O'Diam KM, Daniels KM. 2015. Examination of weekly mammary parenchymal area by ultrasound, mammary mass, and composition in Holstein heifers reared on 1 of 3 diets from birth to 2 months of age. J Dairy Sci. 98:5280-5293.

Esselburn KM. 2012. Ultrasonography evaluating of mammary parenchyma growth in preweaned Holstein Heifers (Thesis). [Ohio (USA)]: The Ohio State University.

Ibrahim L. 2008. Produksi susu, reproduksi dan manajemen kerbau perah di Sumatera Barat. J Petemakan. 5:1-9.

Meyer MJ, Capuco AV, Ross DA, Lintault LM, Van Amburgh ME. 2006. Developmental and nutritional regulation of the prepubertal heifer mammary gland: I. Parenchyma and fat pad mass and composition. J Dairy Sci. 89:4289-4297.

Nishimura M, Yoshida T, El-Khodery S, Miyoshi M, Furuoka H, Yasuda J, Miyahara K. 2011. Ultrasound imaging of mammary glands in dairy heifers at different stages of growth. J Vet Medic Sci. 73:19-24.
Suhardono. 2004. Penyakit dan upaya penanggulangannya untuk menekan kematian pada kerbau. Prosiding Seminar dan Lokakarya Nasional Peningkatan Populasi dan Produktivitas Ternak Kerbau di Indonesia. Banjarmasin (Indones): Dinas Peternakan Provinsi Kalimantan Selatan bekerja sama dengan Pusat Bioteknologi LIPI.

Sutama I-K. 2008. Pemanfaatan sumberdaya ternak lokal sebagai ternak perah mendukung peningkatan produksi susu nasional. Wartazoa. 18:207-217.

Szymańska E, Nowicki A, Mlosek K, Litniewski J, Lewandowski M, Secomski W, Tymkiewicz R. 2000. Skin imaging with high frequency ultrasoundpreliminary results. European J Ultrasound. 12:9-16.

Wortsman X, Navarrete N. 2017. Two-dimensional and three-dimensional ultrasound of artificial skin. J Ultrasound Medic. 36:225-230.

Wirdahayati RB. 2007. Upaya peningkatan produksi susu kerbau untuk kelestarian produk dadih di Sumatera Barat. Wartazoa. 17:178-184. 